\title{
Teaching Remo Dance Art Using Surabaya Style to Improve Primary School Students' Character Building
}

\author{
Farida Utami \\ State University of Surabaya \\ Jawa Timur, Indonesia \\ utamifarida07@gmail.com
}

\begin{abstract}
This study aims at finding out the lesson about education for the fourth graders of education at SDN Sedatigede II.

This research was a descriptive qualitative research. In this study, the researchers used the phenomenon of interaction in the school classroom. The object of the research was the learning of dance art that existed in this school for students, especially for elementary school students. The data were collected through interview, documentation and audiovisual materials. The data analysis included data reduction, data presentation, and drawing conclusions or data validity that was done through triangulation embracing source triangulation, time triangulation, method triangulation.

The result of this research shows that the learning of Remo Gagrak dance Surabaya which applied the value of character education was involved giving stimulation to the students. Such dance applied the value of the character building so that the students could apply the value of discipline, responsibility, confidence, the sense of nationalism, and politeness with the environment culture, in order to achieve the learning goal.
\end{abstract}

\section{Keywords-Learning, character, arts}

\section{INTRODUCTION}

Elementary school becomes the basic foundation in the character building of learners (Isjoni, 2006). The basic level is the beginning of the beginning in which the children get knowledge and build character values that will be useful in their life. Parents and teachers need to work together in directing children to have individual intelligence including academical, spiritual, and emotional intelligence. SUch formation is done gradually and adapted to the portion of the development of the child following the time. At this time, the child is taught a variety of science or subjects which are relevant to their age level which, of course, supports the continuation of education to a higher level.

On the other hand, the mental revolution proclaimed by President Joko Widodo in the Birthday
Ceremony of Employees of the Republic of Indonesia December 1, 2014 has three goals. The first target is turning the mindset into a serving bureaucrat, the second objective is the lean structure, and the third goal is culture and culture [1]; [2] This mental revolution aims at reshaping the mental state of government and society in a state associated with Trisaksi teachings that Bung Karno conveyed in his 1963's speech, namely "politically sovereign Indonesia", "economically independent Indonesia", and " socio-cultural" [2] Then, what to do with the remake learning of gagrak dance?

Dance learning has a role in the formation of a personal or mental harmony. Dance focuses on the needs of emotional development and social intelligence. The emotional intelligence is achieved by self-actualization through motion for it requires a good art appreciation and competence in expressing it. Meanwhile, social intelligence can be achieved by fostering good cooperation with the coach or between dancers, that should be cheerful and confident.

The increasing popularity of foreign cultures, such as language, dance and clothing, is a major threat to Indonesian nation. The problems that will arise will be dealing with the existence of values, morals and characters of the Indonesian nation. The rapid influence from outside / foreign cultures lead to the need of the development of character through the educational path of character building [3] The character building is done by involving the aspects of knowledge,

To achieve the character's education goals, it can be done through a dance in accordance with the learning program that has been designed previously. Dance learning activities are not far from the supervision of various aspects such as cognitive, social, emotional, motor, language, and independence development. According to [4], through art (dance, music, painting) development, the aim is addressed for children to create something based on their imagination in order to develop their sensitivity, and to appreciate the creative outcomes, feelings and actions. 


\section{LITERATURE REVIEW}

\section{A. Instructional Media}

[5]The position of Remo dance as a process and cultural product needs to be well studied. The presence of value in dance deals with the ability to provide clues on how big and close the interconnection of humans is, as a microcosm. The concept of dance and the purpose of dance are not just a series of beautiful movements, but more than that. Dance is a characteristic of humans. As an illustration, Yogyakarta dance which is known as elegant, smooth, flexible, is a characteristic of individuals who can bring themselves as a personal figure of fun, calm, flexible in all circumstances through subtle language. In other words, when people recognize the look of the dance, they will be able to give an interpretation of the dance.

The wide variety of dance in Indonesia reflects the cultural diversity of this nation. However, in this case, through one branch of art, dance / dance makes one way for the introduction of local culture in the younger generation. In each dance (local), there are moral messages that can be conveyed in a fun way, because while enjoying the performances, the spectacles (which is packaged with the order) also incorporate the guiding values.

A good work of art usually carries a message, such as moral, aesthetics, idea, thought, or political ideas. Because the message is an 'appeal' that can affect attitudes and behavior, then, art has an important role in the moral education of the nation. Dance can help learners toward the formation of a person who are closely related to the formation of social attitudes. They are indirectly aware that each individual consists of three dimensions, namely as the creatures of God, as individual beings, and as social beings. Learners are not only brought up into materialistic humans, but suggested to be able to appreciate and implement the values of manners in everyday life.

Aesthetic guidance and education through the art of dance for example, is significant enough to channel the emotions of learners towards a good personal formation. Aesthetic education makes them able to appreciate the beauty, refinement, order and discipline. It is understood that the essence of performing arts is human conflict. Attention to the humanitarian conflict is the basis of the art performance.

\section{METHOD}

\section{A. Development style}

The development design in this research used the ADDIE development model developed by Lee and Owens. The reason for using this model was because the model was a procedural model in which (1) it was descriptive model, showing clear and careful steps to produce the product, (2) the development stages in this model were the same as the standard development stages, but the current model is specially designed for multimedia learning. This is in accordance with the product to be developed [6].
The cultivation of creative value of the learners through dance was done by one way of introducing creative dance. Creative dance is a dance that is played by searching for ideas of motions and tools that are full of values and norms which are also useful for students to understand and search the balance of search results according to ability with full awareness or without coercion. In other words, learners are directed to create creative dance that moves together.

Possible conditions for learners in creating creative dance products is when personal conditions and environmental conditions are sufficiently supportive or conducive to provide auditive, visual, kinesthetic, idea and feel stimuli for not imitating or imitating the work of others. Creative dance works are given as a stimulus and limited knowledge for learners [7]

Learners will be more excited if a material taught in accordance with the needs of students. Learning resources can be any kind of tool / media or situation that can help and enrich and clarify learners' understanding of something they are learning and even help students enrich their experience. In the lessons of dance, the effective medium is to practice the dance motions directly. Students were expected to be able to display the dance form well and correctly.

Learners who get along with the art, in addition to feeling and living the harmony and beauty of art, also have the experience of the soul of sharing feelings and living inner turmoil or conflict, whether it is human conflict between one another, between human with the environment, between human with nature, between human beings with rulers, or perhaps even between human beings with God.

Learners have a relatively deep view of human nature and life. Through art performances, learners gain an understanding of the psychology of human nature. Departing from there, they will gain a more basic knowledge of the nature of other human beings (in general) and about themselves. The dance performed regularly or continuously has a positive impact, as they tend to become sociable with others regardless of the social status. They can respect each other's opinions, work with others, patiently listen to the conversations of others (friends and teachers).

The art of dance provides an opportunity to study human psychology with its various behaviors. They have the opportunity to practice dance. Practice dance is lived properly, then, unknowingly, the process will help in the process of growing maturity. They identify the characters they bring, and also recognize the problems of the character. Similarly, they know exactly the values (moral) that they are struggling for so that they are also trained in solving their own problems in everyday life.

In the process of learning dance, teachers should be able to create an atmosphere of freedom of movement for the students. Teachers are expected to guide students to express their own unique way of moving accordingly and how 
to move according to their feelings. The form of teacher activity in guiding students to learn to dance, are: (1) the practice of preparing the body as a mean of expression, (2) the exercise of the movements of the head, hands, body, and feet to raise awareness to the students that all members of the body are the source of dance, (3) moving exercises with rhythm for the purpose of introduction (4) moving exercises with direction for the purpose of familiarizing the student so that they can quickly adjust to the dance venue, (5) moving practice by formation for the purpose of practicing concentration so that they can quickly adjust to the place of dancing and practice the ability to work together in groups [8] The forms of traditional dance art for school students is one type of dance that consists of several clumps namely; (1) clumps dance game, (2) Folklore, (3) Clump dance creations, and (4) classical dance class such as dances of children game like dance clumps, clumps of folk dance, clump creations and umpun classical dance which has a raw rule that it cannot be changed. The existence of this children dance is very necessary considering the contained values to cultivate the personality of school students in addition to grow the love developed early on the love of traditional values, and other factors which are considered positive for education.

\section{RESULT AND DISCUSSION}

The function of art as a medium of education makes art has a great potential not only for entertainment only but also for the planting of characters that can be taught through the art of dance. The effectiveness of art as a message delivery is done with a touch of beauty. Through the art, all parts of the brain are involved in message processing. So far, the learning of dance is given through the standard patterns so that the learners only imitate the dance of the teacher alone without a few students can issue the ideas of creativity or dance given by the teacher which is not appropriate with their age. Therefore, it makes children tend to be more passive, selfish, rigid and not creative.

\section{CONCLUSION}

According to KBBI [9], creativity is the ability to create i.e. the ability of a person to produce the composition, products, or ideas that are still fresh (new) and previously unknown. A dance-oriented learning approach to children's centers in schools basically refers to the principles of learning.
The learning-oriented on the principles of children development is one of the students' way to learn well when the physical needs met and feel safe as well peaceful in a psychologically.

A creative dance is a dance that is played with searching for ideas of motion and tools that are full of values and norms that are useful for students to understand and seek a balance of search results according to the ability with full awareness or without coercion. The conditions that enable a person to create meaningful creativity dance products are personal conditions and environmental conditions that are sufficiently supportive or conducive to provide additivity, visualization, kinesthetics, idea and the stimuli of not imitating or imitating the work of others.

The students' interest will arise if the material taught matches the needs of students. The learning resources can be any kind of tool or situation that can help and even enrich and clarify the students' understanding of something they are learning as well as help them enrich the experience.

\section{REFERENCES}

[1] H. A. Ahmadi and W. Supriyono, Psikologi belajar. Rineka Cipta, 1991.

[2] O. Sutisna, “Administrasi Pendidikan,” Bandung: Angkasa, 1989.

[3] N. Saibul, Z. M. Shariff, K. G. Lin, M. Kandiah, N. A. Ghani, and H. A. Rahman, "Food variety score is associated with dual burden of malnutrition in Orang Asli (Malaysian indigenous peoples) households: implications for health promotion," Asia Pac. J. Clin. Nutr., vol. 18, no. 3, pp. 412-422, 2009.

[4] U.-U. R. I. N. Depdiknas and R. I. No, "Tahun 2003 Tentang Sistem Pendidikan Nasional," Jakarta Dirjen Pendidik. Dasar dan Menengah, 2003.

[5] F. Wibowo, Tari klasik gaya Yogyakarta. Yayasan Bentang Budaya, 2002.

[6] H. P. Setyosari, Metode penelitian pendidikan \& pengembangan. Prenada Media, 2016.

[7] A. P. K. M. P. Seni, “ADAPTASI KURIKULUM PENDIDIKAN SENI TARI DI SEKOLAH SEBAGAI SARANA PENDIDIKAN KARAKTER BANGSA Oleh."

[8] N. Z. Haron, S. A. M. Junos, A. H. A. Razak, and M. Y. I. Idris, "Modeling and simulation of finite state machine memory Built-in Self Test architecture for embedded memories," in Applied Electromagnetics, 2007. APACE 2007. Asia-Pacific Conference on, 2007, pp. 1-5.

[9] K. Tim Penyusun, "Kamus Besar Bahasa Indonesia," Balai Pustaka: Jakarta, 2008. 